\title{
IRISH STUDIES ROUND THE WORLD - 2019
}

\section{Christina Hunt Mahony (ed.)}

Copyright (c) 2020 by the authors. This text may be archived and redistributed both in electronic form and in hard copy, provided that the author and journal are properly cited and no fee is charged for access.

\section{Introduction}

Christina Hunt Mahony

A History of Irish Modernism.

Gregory Castle and Patrick Bixby, eds.

Feargal Whelan

Constellations: Reflections from Life.

Sinéad Gleeson

Melania Terrazas

\section{Dublin Palms.}

Hugo Hamilton

Denis Sampson

Making Integral: Critical Essays on Richard Murphy.

Benjamin Keatinge, ed.

Elsa Meihuizen.

The Collected Letters of W. B. Yeats, Volume V: 1908-10.

John Kelly and Ronald Schuchard, eds.

Nicholas Grene.

Over the Backyard Wall: A Memory Book.

Thomas Kilroy

George O'Brien

A New History of the Irish in Australia.

Elizabeth Malcolm and Dianne Hall

Pauric Travers

Notes to Self.

Emilie Pine

Éilís ni Dhuibne. 
Oscar Wilde and Contemporary Irish Drama: Learning to be Oscar's Contemporary. Graham Price

Pierpaolo Martino

Emergency Writing: Irish Literature, Neutrality, and the Second World War. Anna Teekell

Christina Hunt Mahony.

James Joyce's Silences.

Jolanta Wawrzycka and Serenella Zanotti, eds.

Teresa Prudente

\section{Introduction}

\section{Christina Hunt Mahony}

Conferences come and conferences go, and they have certainly proliferated in Irish Studies in recent years, but it could be maintained that IASIL (previously IASAIL) was the progenitor of them all. This year the International Irish Studies organisation celebrated its $50^{\text {th }}$ year with a conference in Trinity College, Dublin, where the first such gathering was held. Organised by the School of English, and in the capable hands of Tom Walker, the conference drew the largest number ever to attend - in the region of 400 - and at times ten simultaneous sessions were held. High points were keynote lectures by Matthew Campbell to open, and Nicholas Grene to close, and old and new friends from Spain, France, The Netherlands, Belgium, the UK, Canada, the US, Brazil, Japan and many other countries, joined Irish members, to say goodbye at the closing reception in City Hall in Dublin. President Ondřej Pilný meanwhile had undertaken to have a $50^{\text {th }}$ anniversary commemorative document sent to all delegates in attendance, which included a photographic history of IASIL, lists of founder members and the venue for all the conferences, and much more to jog our memories and for us to cherish.

Irish Museums in 2019 presented a vibrant selection of visual experiences for the visitor. Of course the magnificent Sorolla exhibit at the National Gallery will have caught the eye of many Estudios Irlandeses readers, but would have introduced many Irish museum goers to a painter they might not have had the pleasure of seeing in the past. And, travelling from Merrion Square across town to Stephen's Green, visitor and native alike could discover the new literature museum, MOLI (Museum of Literature Ireland), which opened its doors in the stunningly renovated Number 86 in a collaborative effort of UCD and the National Library of Ireland. Here the curious can experience the written word transformed to both visual and aural experiences. And MOLI boasts an excellent café, with patio seating and access to Iveagh Gardens, along with a well-stocked gift shop.

Outside the capitol The Crawford in Cork is hosting an ongoing exhibition of both the stained glass and watercolours of Harry Clarke. (See also the splendid new book on Clarke, Dark Beauty, published recently by Irish Academic Press). And in Limerick, the often overlooked Hunt Museum presented an excellent summer exhibition on the parallel careers of Sir John Lavery and Walter Osborne, which brought together many works from private collections; and continuing into 2020 at The Hunt is Time, Tide, paintings by Hughie O'Donnell which are the product of childhood memories of visits to his mother's home place on the coast of County Mayo.

The festival season in Ireland is year round now - but one of the major summer offerings, at The Galway Arts Festival, was Irish National Opera's Least Like the Other, 
searching for Rosemary Kennedy, a work which explored the life of the hidden child of the Kennedy family, bringing to mind recent works in various genres about Lucia Joyce, both famous daughters and female victims of early psychiatric practice. In the autumn, one of the highlights of the Dublin Theatre Festival was presented at The Gate under the stewardship of its new artistic director, Selina Cartmell. A Dead Centre production, co-directed by Bush Moukarzel and Ben Kidd, Beckett's Room, is a highly imaginative rendering using no actors on stage, but is voiced, and exhibits puppeteering skills to tell an imagined recreation of the dangers experienced by Beckett and his partner, later wife, Suzanne Dechevaux-Dumesnil, while they were active in the French resistance during the Second World War. Another brilliant offering in the theatre festival was Rough Magic's production of Marina Carr's Hecuba, with Aislin McGuckin in a riveting performance in the title role, adroitly directed by Lynn Parker. Later still, December brought another Beckett production at The Project Arts Centre. Pan Pan Theatre Company, under the direction of Gavin Quinn, presented Endgame which saw the reunion of famed veteran Irish performers, Rosaleen Linehan and Des Keogh as Nell and Nag. And Irish dramatic productions continue to draw grateful audiences abroad, as indicated by the recent reception of Druid Theatre's Richard III at Lincoln Center in New York.

To limit the choice of film and television offerings this year to just one in each medium, Irish filmgoers were well-served by Dark Lies the Island, directed by Ian Fitzgibbon with screenplay by the inimitable Kevin Barry. The tale of a highly dysfunctional midlands family, it stars comedians Pat Shortt and Tommy Tiernan in serious dramatic roles, along with the excellent Charlie Murphy as a young wife who is, shall we say, overly fond of both her stepsons. But if Barry's film gives a rather sordid picture of Irish family life, the other end of the spectrum is beautifully delivered by the BBC's offering, The Music of What Happens, a documentary of Seamus Heaney's life, featuring his wife, children and siblings, along with former students and colleagues. Anyone able to access the BBC player should be certain to make this excellent work priority viewing.

And books, books, books... where to begin? Perhaps beginning at an ending might be a novel choice but Ann Enright's No Authority: Writings from the Laureateship, is a selection of lectures given throughout Ireland during 2015-2018, and chosen by Ireland's first Prose Laureate after she had passed the baton to Sebastian Barry. Enright considered the post a civic duty and set the bar high. Not surprisingly many of the finest essays are feminist in their orientation and all the more powerful for it. Another impressive offering comes in the elegant form of Winter Pages 5, an annual arts anthology edited by Kevin Barry and Olivia Smith. Its $€ 40$ price tag is somewhat off-putting, but its a splendid book brimming with talented contributors too numerous to list. And, for those who want to be au courant with Irish affairs in both a political and literary context there are two very different books from which to choose. The first, Correspondences: An Anthology to Call for an End to Direct Provision, edited by actor Stephen Rea and poet Jessica Traynor. The contributions are written by people who have lived in Ireland's Direct Provision Centres and who share their stories of hardships endured both in their native countries and after their arrival in Ireland. The second topical choice is I am the Border, so I am, which began life on twitter (@BorderIrish, with over 82 thousand followers, including Taoiseach Leo Varadker) and is the arch testimony of an anonymous writer who has anthropomorphised the border between the Republic and Northern Ireland as a means of illustrating the infuriating, sad, and hilarious anomalies occurring in discussions about same in the Brexit ongoing negotiations.

2019 was a year in which we said a final farewell to two figures well known to those in Irish Studies and whose contributions to Irish life were immeasurable. Gay Byrne, radio and television broadcaster and father figure in Irish media, was a major force in the modernization process that Ireland underwent belatedly and rather quickly in the mid- 
twentieth century. The son of a Guinness worker and the grandson of a footman to the Earl of Meath, Byrne - especially as host of RTE's Late, Late Show - nudged the boundaries of social, political and religious acceptability throughout his illustrious career. And North of the border, poet Ciaran Carson, one of that great band of mid century poets who emerged during The Troubles, was working until the time of his death and his final collection, Still Life, has recently been published by Gallery Press. The learned Carson was equally at home in a number of genres, being as he was a native Irish speaker and accomplished musician who was recognised for his translation skills (his version of Dante's Inferno is considered to be one of the finest of the era) and who left us a number of poignant memoirs.

Christina Hunt Mahony is the former director of graduate Irish Studies at The Catholic University of America in Washington, DC. She is the author of Contemporary Irish Literature: Transforming Tradition and Out of History: Essays on the Writings of Sebastian Barry. She is a recent contributor to The Oxford Handbook of Modern Irish Theatre, ed. Nicholas Grene and Chris Morash, and to A History of Irish Autobiography, ed. Liam Harte.

cmahony@tcd.ie

\author{
A History of Irish Modernism. \\ Edited by Gregory Castle and Patrick Bixby \\ Cambridge: Cambridge University Press, 2019. 427 pp. \\ ISBN: 978-1-1071-7672-0
}

\title{
Reviewer: Feargal Whelan (Trinity College, Dublin)
}

In a recent review of two studies of the European architects and designers Mathias Goertz and Gyorgy Kepes, both of whom developed successful careers in Mexico, Jed Perl details the antagonism exhibited by the Muralist native artists of Diego Rivera and David Quiseiros to the Modernist aesthetic embraced by the two Europeans. Simply put, the clash was portrayed as a struggle between the nativism of the Mexicans, drawing off the indigenous mythology, rooted in the nativist ethos of the pueblo mejicano against the cosmopolitanism of the modern natives of mitteleuropa, which claimed to have abstracted itself from such exceptionalist and nationalist concerns. Yet, Perl points out, the actuality of the conflict subtly exposes the reality that both sides paradoxically adopted the concerns of the other (Perl 2). This need for nuance in an apparently binary narrative always appears to me to be essential, though often lacking, in any examination of recent Irish cultural history and it is one which is thankfully foregrounded in a pivotal article in A History of Irish Modernism. In his chapter "Internal Others: Cultural Debate and Counter-Revival”, Rónán McDonald assesses the frequently accepted binary that pits "Irish Modernism" in the one corner against its supposed counterpart "the Cultural Revival" in the other, and concludes that what lies "beneath the debates about cosmopolitanism and nationalism" is not two fixed and irreconcilable viewpoints but in fact "a subterranean interdependence" (104) with each both defining and enabling its counterpart. McDonald's assertion that Irish Modernism's engagement with the Irish revival is the central dynamic of the phenomenon is not unique, in fact it underpins most of the studies in this collection, but his thesis that the concerns of the one are so frequently addressed in a similar 
way in the other, is so compelling that it provides a helpful template with which to address the various artists and movements covered in the rest of the book.

The book's editors, Gregory Castle and Patrick Bixby, exemplify McDonald's thesis in their examination of Standish O'Grady, the essential "father of the Revival", in which they argue that the impulse which drove the initial movement, the recalibration of the historical, allowed any Irish modernist the ability to "address the disjunctive forms of modernity" by providing a complicated and sophisticated treatment of temporalities "that defy the simple opposition of the traditional and the modern" (59). In effect, the Revival becomes the very reason for the apparently remarkable ability of Irish authors to define modernism so thoroughly. Derek Hand rehearses the same theme in his survey of Irish novel writing from 1922 onwards, in which he challenges the accusation of provincialism and inertia made against writers of the post-independence era, and, in particular, the opinions of Sean O'Faolain. Hand demonstrates that the focus of the novelists turned inwards and towards the actuality of the new state requiring the "need to find new modes and new techniques to give expression to a new political and cultural dispensation" (244) and it is here that the flexibility of approach, suggested by Castle and Bixby, was successful. Hand's elucidation of the "internationalism" of neglected authors such as Eimear O'Duffy, Austin Clarke (as novelist), and Liam O'Flaherty provides a riposte to O'Faolain, as does Hand's reading of Molly Keane and Elizabeth Bowen as a literature of estrangement, critiquing "an existential and ontological crisis" not just with Ireland but "with modernity itself" (253).

There is a problem for any book which is styled a "A History of...", in that it needs to be all-encompassing by nature, and even "definitive", yet offer something new. The editors' task becomes more difficult here because, although this history is the first of its type, it must negotiate the "big beasts" of Joyce, Beckett and Yeats, who have such huge individual critical canons. The book must also accommodate neglected writers, such as George Egerton or Seán Ó Riordáin, about whom the audience might know little. The difficulty is seen in Joe Valente's chapter on Ulysses which not only engages Joyce and Irishness, but also challenges recent Joyce criticism he describes as "pro-Nationalist" (225), using the Cyclops episode as an exemplum. His argument, that the episode is neither a critique of the exaggerated nationalism of "the Citizen", nor an exercise in anti-Semitism towards Bloom, but is instead an extended attack on populism per se is both elegant and timely, but it feels more like an excellent intervention in an ongoing debate, which might have been enhanced by a broader companion piece on Joyce. Such a balance was achieved in relation to Beckett where Emilie Morin's excellent meditation on "distancing" and late modernism in his work is augmented by Luke Gibbons' exploration of Beckett, Thomas MacGreevy and Irish art.

There is an admirable recognition that Irish Modernism must encompass the visual arts as well as the literary, and in this context, Ellen Rowley's chapter on Irish architecture is one of the most rewarding in the collection. Taking a point of view from the pivotal year of 1966, the fiftieth anniversary of the Easter Rising, Rowley surveys the architectural history of the state detailing the tangible struggle between modernism and traditionalism, and depicts it as one of the most observable cultural conflicts, and also its most socially impactful, in Ireland's story. While Luke Gibbons gives an excellent account of the crucial relationship between Samuel Beckett and Thomas MacGreevy, triangulating their ideas on art in general with their opinions on their mutual friend Jack Yeats, it seems a pity that the excellent survey of the role of Irish painters and designers, centred on the foundation of the Irish Exhibition of Living art in the 1940s was not given more space. In the same vein, Clare Hutton's survey of Irish book production, from the Yeats sisters Dun Emer press, through Maunsell \& co. and the Talbot Press, rightly accords a central significance to the role of indigenous publishing in local artistic development. 
The frequently neglected position of literature in Irish is admirably covered by Barry McCrea. Arguing that Irish might have been more suited than English to engaging with the tropes of disintegration and alienation because of its recent history, McCrea emphasizes the anxieties and difficulties surrounding the revival of the language before tracing a line of modernism through Seán Ó Ríordáin, Máirtín Ó Cadhain and Flann O’Brien. It is precisely because of its status as a declined language and, what he describes as "its strange afterlife as a learned language" (328) that made Irish almost more appropriate to a modernist mind, McCrea convincingly argues. Equally, Gerardine Meaney's study addresses the issue of women's writing (still frequently marginalized in books of this type) asserting the crucial role of Kate O'Brien to the modernist effort in Ireland, but also foregrounds the work of Dorothy Macardle, Maura Laverty and Rosamund Jacob in the Irish Women's Writing Club.

Adrienne Leavy gives a comprehensive description of Irish modernist poetry, which to begins promisingly with the arrival of Thomas MacGreevy, Brian Coffey, Denis Devlin, Beckett and Blánaid Salkeld on the literary landscape (and the more recently collected Ethna McCarthy who is absent here) but who faded quickly from prominence. However, Leavy makes the case for reading a line of descent through Louis MacNeice, Patrick Kavanagh, John Montague and Thomas Kinsella. Paige Reynolds provides an insightful reading of Sean O'Casey's drama arguing for them to be read distinctly as examples of late modernism by virtue of their having being inflected by a critique of high modernism in the aftermath of the First World War. Reynolds cites The Silver Tassie as an example of O'Casey's move to expressionism. Unusually for this volume, Reynolds makes a case for observing a route of influence on the contemporary Irish stage by citing the 2016 production These Rooms as a thematic and stylistic remnant of O'Casey, attesting to its endurance in Irish practice, she argues.

The coincidence that political independence became a reality in Ireland in exactly the same year as the publication of two of the emblematic pillars of modernist writing, Joyce's Ulysses and Eliot's The Waste Land, has been frequently remarked upon, but it may feed into a broader sense of Irish exceptionalism in relation to the nation's status in world culture. This further complicates the actuality of cultural production in Ireland following the inception of the new state, with its competing influences of conservatism and liberalism, of poverty and hope. Gerardine Meaney points out that it is

problematic ... to distinguish between high and low modernism in Ireland from the 1930 s to the 1960s unless it is understood in terms of a continuum of cultural practices rather than a polarized binary of modernism and realist, experimental and popular. (288)

and it is notable that throughout the book, such contradictions and conundrums are duly exposed and dealt with. The book might suffer from an imbalance in its treatment of the Yeats brothers, with Willie far too privileged over Jack who probably deserved a chapter to himself. Omissions in any book which attempts to comprehensively cover a lengthy and busy period are readily found, and in this book, the light shone on neglected figures and works easily balances the apparent gaps. One gap I do regret was that of the work of the Gate Theatre - its contribution to new forms of theatre; its commitment to the international and the reimagining of the developing state; its championing of cinema as an art form, and its performance as a site of cultural disruption, quite apart from its dramatic canon. However, the book achieves its goal through the course of its twenty three chapters and should be regarded as a serious collection. 


\section{Works Cited}

Perl, Jed. "Hell Bent Idealists". The New York Review of Books. 10 October 2019. 11 October 2019. www.nybooks.com/articles/2019/10/10/mathias-goeritz-gyorgy-kepes-hell-bentidealists/?printpage=true.

Feargal Whelan is a research associate at the Trinity Centre for Beckett Studies in Trinity College Dublin. He has published and presented widely on the work of Samuel Beckett and on twentieth century Irish drama. He edits the Beckett Circle and is a board member of the Samuel Beckett Society.

feargal.whelan@gmail.com

Constellations: Reflections from Life.

Sinéad Gleeson

London: Picador, 2019. 246 pp.

ISBN: 978-1-5098-9275-4

\section{Reviewer: Melania Terrazas (University of La Rioja)}

Constellations: Reflections from Life, a first book of personal essays by the Irish Book Award-winning writer, editor, book and music reviewer, and freelance broadcaster Sinéad Gleeson, is one of those narratives about the fe/male body in pain and struggling for recovery that never leaves the reader indifferent. From Jean-Dominique Bauby's The Diving-Bell and the Butterfly (2008), which records his ability only to move one eyelid after suffering a massive stroke, to Susannah Cahalan's Brain on Fire (2012), which narrates a serious bout of autoimmune encephalitis, which caused her to lose her memory, body mobility and identity for a month, narratives of this type are unique and inspirational. They embody a response to the question, "What can I do to change the present situation?" However, Gleeson's Constellations does more than that; it is an example of how music and words can save one's life and how writing the female body in pain and in culture and can help to give some sense to, and change, women's lives in society.

Constellations is so titled perhaps to impart an "astronomical" feel or to relate it to an assemblage, collection or group of usually related persons, qualities or things. Whatever the case, Constellations is all of that, as the collection narrates Gleeson's experiences of two deadly illnesses (monoarticular arthritis and acute promyelocytic leukaemia, APML), the first as a teenager, and the latter before her first pregnancy. The collection revolves around these two significant diagnoses and their impact on her female self and body. However, Gleeson's reflections from life also touch upon the lives of a large number of public and historical figures, in multiple fields and countries, their deeds, emotions, illnesses, the impact of their work on culture and society. In addition, the book explores many cultural constructions relating to gender, identity and trauma issues. Gleeson's essays cover a large historical time span, until its year of publication, 2019, a year for reflection, filtered in part through the repeal of the Eight Amendment from the Irish Constitution on 25 May the year before, when Ireland paved the way for legalized abortion. 
Constellations is a powerful first-person narrative, and this device offers the reader insight into Gleeson's reworking of her material as her life story unfolds. The collection is divided into fourteen essays, each unusually, but aptly, titled with different constellations. With aplomb Gleeson pulls off the feat of turning long-term pain, shock, fear, anxiety, frustration, despair, rage, shame, and profound gratitude for medical care and loved ones into a unique book. Yet Constellations is not just a retrospective exercise in self-reflection about two serious illnesses; it also ponders at length on Gleeson's body and life as a woman in Ireland in her roles as a daughter, a patient, and in a variety of social and familial roles. Constellations constitutes a brave, determined and coherent attempt to dwell upon the female self/body in Ireland. Gleeson's work also shows her mediating role as a social writer who, in holding a mirror up to politics, presents an original view of social change in the Irish context and of what the future will or could be like. Her acute consciousness of the bigger picture leads Gleeson to regret a lack of empathy and sensitivity among Irish male doctors while she was ill and in treatment. She also condemns the denial of Savita Halappanavar's request for an abortion, then illegal under Irish law, resulting in her death from septic miscarriage. Although published nearly two decades after Linda Connolly's 2002 book on the Irish women's movement, Gleeson's Constellations can be considered another "starting point of analysis" that "spawns wider questions about feminism as an agent of political and social change" in Ireland. ${ }^{1}$

Gleeson's Constellations reveals her wide and multifaceted knowledge of music, culture and literature, which bring to life her two passions in evocative words and innovative aesthetic forms, making the material vital and experimental. However, Gleeson's emotional intelligence in recalling her life experiences and her knowledge of the language of medicine in narrating the culture of the female body with so much adroitness result in a book that produces a reading experience with multiple layers, causing both pain and pleasure. Constellations facilitates learning and growth, and above all, provides intellectual satisfaction in the comprehension of a complex issue.

Constellations also has a modernist encyclopaedic nature. It is a unique non-fiction example of synaesthesia and of the multiplicity of sensibility that informed many modernist artworks. This occurs not only because when reading about pain in Constellations one experiences a concurrent subjective physical feeling other than the one being discussed, but also because one perceives the written material with more than one sense at once ("The synovial fluid in my left hip began to evaporate like rain. The bones ground together, literally turning to dust. It happened quickly, an inverse magician's trick. Now you don't see it, now you do"). In other words, just as sensory responses converge when reading Constellations, so are mental reflections combined with such sensorial reflections. Gleeson's book is modernist, too, because of the enormous amount of medical, artistic, cultural, historical or critical reflections on the female body narrated within it. From Karl Landsteiner, Frida Kahlo, Roald Dahl, and Dervla Murphy to the Magdalene Laundries, Gleeson's collection is allusive and inter-textual and hints at many other meanings, but leaves it to the reader to link the ideas and create meaning. If one adds to these characteristics the large number of themes, such as blood, contraception or dementia, forms like poems, letters or constellations, drawings of Gleeson's modernist artistry, and her interest in a wide range of cultural practices and life experiences around the female body in pain, the scope of her collection expands exponentially. Thus, Gleeson dwells upon the fe/male artist's idea of the body in a large number of cultural practices from many places and times, and produced by artists of different sex, race, class, ideology, religious belief and nation. Consequently, practically everything is the object of consideration in Constellations. In this context, this Irish bestseller will be an important contribution to the new perspectives on the influential narrative of the female body in pain and change, and not only in Irish culture. ${ }^{2}$ 
In sum, Gleeson's Constellations is to be praised for her most generous, poignant and riveting literary reflections on life. Her collection is a real page-turner and deserves worldwide attention, not just because it may remind readers of similar past traumatic episodes, may awaken dormant emotions and fears, or evoke many feelings and emotions in brilliant ways. Gleeson's book is also of merit because no matter how many times readers go through surgery like Gleeson, or how serious these readers' illnesses may be, creative exercises of the imagination, such as this collection of essays, remind readers, in their daily routine, of how precious their health is and how trivial other matters are. Constellations will be published in the United States by Mariner HMH books on 24 March 2020, with events and press in New York that week.

\section{Notes}

${ }^{1}$ Linda Colley. The Irish Women's Movement: From Revolution to Devolution. Dublin: Lilliput, 2002. xii

${ }^{2}$ A very good example of this is the most recent viral piece by student of creative writing Caragh Maxwell in The Irish Times, "I hoped to God that I'd just die in the night and get it over with". 16 February 2019. 15 December 2019. <https://www.irishtimes.com/culture/books/i-hoped-to-god-that-i-d-just-die-in-the-night-andget-it-over-with-1.3781474>

\section{Works Cited}

Bauby, Jean-Dominique. The Diving-Bell and the Butterfly. London: Harper, 2008.

Cahalan, Susannah. Brain on Fire. London: Penguin, 2012.

Connolly, Linda. The Irish Women's Movement: From Revolution to Devolution. Dublin: The Lilliput Press, 2002.

Melania Terrazas is on the Executive Board of AEDEI, head of the Centre of Irish Studies BANNA/BOND (EFACIS) and Senior Lecturer in English Studies at the University of La Rioja (Spain). She is the author of Relational Structures in Wyndham Lewis's Fiction: Complexity and Value (Lincom, 2005), the guest editor of Journal of English Studies, vol. 8. (2010) and Gender Issues in Contemporary Irish Literature (Estudios Irlandeses, vol. 13.2, 2018) and the editor of Trauma and Identity in Contemporary Irish Culture (Peter Lang, Reimagining Ireland Series, 2020).

melania.terrazas@unirioja.es

Dublin Palms.

Hugo Hamilton

London: 4thEstate, 2019. $277 \mathrm{pp}$.

ISBN 978-0-0081-2812-8

Reviewer: Denis Sampson (Vanier College, Montreal)

The unnamed central character of this novel sometimes becomes the narrator, and this suggests it may be memoir as much as fiction: the reality it depicts is a blend of stream of 
consciousness, memories, conversations, and speculations. Its clean sentences take the reader into a suburban Dublin world and the family that lives there, but the blend of narrative styles questions the reliability of language and storytelling, and questions too the notions of home and self.

"I grew up in a language nightmare. Between German, Irish and English . . . [My mother] came to Ireland to learn English, but ended up teaching my father German". This was at the end of World War II, and his mother has happily emigrated, free now from the Nazi world of which she was a victim. Each of his three languages is rich in associations: "This war of languages has left me with a deep silence. I doubt the ground I walk on. I make my way around the city as though I have only recently arrived. Still arriving. Never arriving. My viewpoint is unstable, seen from multiple places at once". The complexity of migration and multiple languages is explored, and while he has lived for a time in Berlin, and returned to Dublin, he cannot speak of Ireland as home.

His father became a nationalist revolutionary who was doctrinaire in his belief in the revival of Irish. He insisted that the family use it as the home language, and the narrator was sent to school in the Irish language. Now employed in the recording department of the revival organization, nevertheless he refers to it in a detached way: the native language, the dead language, the ghost language, the endangered language. "Everything in my work is devoted to a silence in the landscape, to what is receding, what is being kept alive . . . I can no longer hide the fact that I am partly dead myself. Half alive. Perhaps undead. As dead as a dead language refusing to die".

Much as he likes the traditional music he records, he speaks of himself as a silent one, and his various silences are associated with the places he has been attached to - the West of Ireland, Berlin, London, Dublin. In fact, this is a novel of a disintegrating self, and there is a mysterious medical condition which he believes explains his odd physical and psychological states.

Mid-way through, he begins to write fiction and completes a story, "Dublin Palms", although the reader is not given any details about it, and he remains silent in life, except in practical ways with his two children, his partner (who is named - Helen), and his mother. Of Irish parentage, Helen was raised in London by her aunt, since her mother left to live in Canada, where she remains and where Helen has frequently visited her. Helen's presence is central as he moves from his isolation to loving and supporting her.

Hamilton's earlier memoir, "The Speckled People", explored many of these situations and themes, and was considered by critics as one of the best European memoirs. In fact, many allusions here may be connected to the memoir. The mother is pleased to have left postwar Germany to settle in Dublin. "It's like being on holiday all your life because you hear seagulls in the morning and you see sailing boats outside houses and people even have palm trees growing in their front gardens. Dublin where the palm trees grow, she says, because it looks like a paradise".

This may suggest why the novel is entitled "Dublin Palms". Rather than being a subtropical "paradise", as it might be in holiday advertising, Dublin appears to be a classic city of the financial crash. They struggle to survive with many debtors harassing them, even though Helen is enterprising as a business-woman and a journalist. But he is not, and he leaves his 'underground' job, a place of silence and depression, in Helen's mind. Yet he loves the city and wishes it were still his home.

Gradually, he realizes something about home and the homes he has left. The palm trees his mother speaks of reflect her adaptation, her creation of a new home. These plants in Ireland are outside their natural home and on the final pages, there is an echo of the beginning: "It has become part of us now, that condition of arriving and not arriving. Going 
away. Returning home. Waving. Embracing. Looking back. Not looking back". Helen and the girls leave for Canada, but he waits: "I was no good at leaving. I started writing a book. My silence began to dissolve. I found a language to be heard in". He writes about his mother's uprooting in the final days of the war in Eastern Europe and her difficulties in travelling to home because of the military and political chaos.

But in recreating in fiction her he finds a voice that is authentically his own. Thus he frees himself from the "nightmare" of languages in his childhood and the silence that descended when he went to Berlin to escape. In the final sentences it appears that his separation from Helen can be overcome: "We can invent new ways of telling who we are and where we come from. We can speak our way home". The achievement of writing this novel appears to be the statement of his freedom to express himself confidently, without the weight of dogmatic stories of history, or place, or identity.

In this brilliantly written novel without a conventional plot, Hugo Hamilton chooses instead to plot the journey from silence to speech. The narrator's life is painful, an echo of his father and other men, but his mother and Helen represent what he must find in this postwar and modern world. It is a very impressive literary achievement.

Denis Sampson, Emeritus Professor at Vanier College, Montreal, is the author of Outstaring Nature's Eye: The Fiction of John McGahern (Lilliput Press); Young John McGahern: Becoming a Novelist (Oxford UP); Brian Moore: The Chameleon Novelist (Doubleday); A Migrant Heart. Memoir (Linda Leith Press) and The Found Voice: Writers' Beginnings (Oxford UP).

denissampson@gmail.com

Making Integral: Critical Essays on Richard Murphy.

Edited by Benjamin Keatinge

Cork, Ireland: Cork University Press, 2019. 362 pp.

ISBN: 978-1-78205-325-5

\section{Reviewer: Elsa Meihuizen (North-West University, South Africa)}

Benjamin Keatinge, editor of Making Integral: Critical Essays on Richard Murphy, states in his introduction that the central concern of this publication is "to show how Richard Murphy has made 'integral' in his poetry a set of diverse experiences - his own and those of others along with incidents from the wider panorama of history and geography, in ways which show the poet seeking definition of himself through others" (2). The essays included in this substantial work indeed succeed in reflecting the diversity, complexity, and broad-ranging concerns of the poetic achievement celebrated, and of its remaining importance both within an Irish and a broader literary context.

One of the important underpinnings of Murphy's poetic achievement evidenced in the studies included here is the autobiographical centre of his writing. This insight forms an important point of departure, or an underlying premise, in several of the essays, as typically expressed in Joseph Sendry's discussion of Murphy's sense of history encapsulated in the concept "aftermath". The critic points out here that complex, sometimes obscure, biographical 
references characterise much of Murphy's work, and that, therefore, not only factual data about his life are often needed to elucidate the poems, but, in order to uncover the poems' multiple layers of significance, Murphy's writing "must also be placed within several interlocking matrices: genealogical, social, national, historical, even world historical" (127). The explanation for this tension between the self and the other can be found, as argued convincingly by Benjamin Keatinge, in Murphy's “... 'impossible' situation as belated Anglo-Irishman in mid-twentieth-century Ireland" (3) which, on the one hand, informs an acute feeling of exclusion, but, paradoxically, also helps him to feel an affinity with the wide range of voices celebrated in his poetry. In several of the essays valuable information is provided on the sources in which Murphy, especially in his later years, documented autobiographical information to assist the reader in uncovering this multifaceted significance of his poetry. These sources include: interviews and radio broadcasts; critical reviews of older and contemporary poets' work; extensive notebooks kept for four decades; his memoir, The Kick; notes on the genetic process of the sonnet sequence The Price of Stone (published initially in Poetry Ireland Review and collected and expanded in In Search of Poetry (2017); and the prose sections included in The Pleasure Ground: Poems 1952-2012 (2013). The indivisibility of Murphy's autobiographical writing from his poetry is underlined in Barbara Brown's account of her first-hand experience of the making of The Kick. In discussing the process of selecting material for the memoir, Brown quotes from one of Murphy's notebooks where, while composing The Price of Stone, the poet states his belief that although the poem is not autobiography, autobiography is one of the building materials you need to construct a poem. Brown reminds us that much of Murphy's poetry can also be characterised as narrative, and that, for instance, the narrative in The Price of Stone corresponds to that of The Kick.

The golden thread running through the narrative of Murphy's life as reflected in his poetry and life writing, is the quest for a secure identity. In his contribution to this publication Maurice Harmon describes the root cause for this quest as "division and distress" (11), and points to a family background divided between colonial Protestant Anglo-Irish and conquered Catholic peasant, an education divided between British rationality and Irish sensuality, aspirations contrasting the rigidity of the rectory and the military with the wildness of the cottage and the sea, and a divided sexuality. One of the decided strengths of the book is the depth of attention given to these complexities that comprise Murphy's identity, and to the ways his writing reflects his efforts to resolve these complexities. In the poet's own words "to look inward at the divisions and devastations in myself as well as in Ireland" (Murphy, The Pleasure Ground 255).

A number of studies focus on the exploration of these "divisions and devastations" offered in the longer narrative poems, The Battle of Aughrim, The God who Eats Corn, and The Price of Stone, drawing on existing critiques, but also offering new insights and perspectives. An important point of consensus reached in these studies (and echoed in the volume generally) is that Murphy's creative work has a universal and timeless quality, and that his concern with the fractured and often conflicting nature of the human condition plays an important role in this achievement. This quality of Murphy's work was not always appreciated or acknowledged, as pointed out by Siobhán Campbell and Tara Stubbs. With reference to an earlier review of Murphy's work, Campbell argues that "the kind of literary criticism of birth, of upbringing and therefore of expected affiliation with which we are all too familiar in Irish letters" (112) often stood in the way of a full appreciation of Murphy's inclusivity of thought reflected, for instance, in The Battle of Aughrim, a poem she regards as "applicable to our violent present", and that "seems to speak directly to our now" (125). Taking as point of departure an earlier judgment detecting an unease and programmatic quality in Murphy's preoccupation with shaping his inheritance into a poetic theme, Stubbs 
explores the shaping of inheritance in The Price of Stone. She sees the accusation of unease "upturned by The Price of Stone, because Murphy places his unease at the centre of things", and she offers the insight that "The ventriloquized 'unease' of Murphy's self-acknowledged 'split mind' becomes instead the bastion of the sequence - at once its cause, its symptom and possibly, also its cure" (221).

The quest for a secure identity informed by division, duality and insecurity is also manifest in Murphy's writing as a search for structure, ranging from the need for a settled, principled way of life, to a preoccupation with physical construction and reconstruction of buildings and boats, to the creation of the well-written word or line. It could be seen as sadly ironic then that the author's life remains marked by "[a] sense of loss, being lost, and of leaving a life behind, unfinished, incomplete" (49), as concluded by Gerald Dawe in his essay focusing on this aspect of Murphy's oeuvre. An important result of Murphy's search for structure is his moving between different geographies, which is also ironic in certain respects. The irony is evident, for instance, in the phrase "fluid geographies" included in Philip Keel Geheber's study of Murphy's poetics of place. Here it is shown that Murphy relates geographical relocation to the crossing of boundaries, transgression of received limits, and to both creative and destructive processes. Similarly, Lucy Collins sees Murphy's gravitation towards the island as both a dwelling place and artistic inspiration, as essentially a move to a place of origin, but also as the articulation of a profound sense of separateness, of reworked temporal and linguistic histories, which "speaks to the radical displacements of our age" (77). Michael J. Moir Jr also points out that, even when Murphy set himself the task in The God who Eats Corn to write a poem in his father's honour, the result is the depiction of a space characterised by instability, encroached upon by violence and disorder.

Arguably, one of the most moving passages included in Richard Murphy's memoir is the poet's account of his father's death and burial in 1965. After describing in characteristic, almost cinematic, detail this traumatic experience within the family, Murphy narrows the focus to his own relationship with his father. This has evidently been a strained relationship, reflected here in Murphy's references to fundamental differences in basic principles and life choices, which for his entire life has made talking to his father difficult. His father had represented, however, a "firmament of power" for him, and Murphy's way of dealing with this loss was to collect "trailer-loads of pink granite from the remnants of seven abandoned cottages near Cleggan, to build a new house out of the old and replace in stone the lost firmament" (Murphy, The Kick 248).

A desire to preserve, to secure for posterity, has been, from a very early age, an important reason for Murphy's ambition to write poetry. The poet writes in his memoir that as a boy he "took refuge in the Renaissance conceit that a poem, if well made, could last longer than its maker, giving life after death to himself and his loved ones in the minds of his readers (Murphy, The Kick 85). I would argue that Making Integral: Critical Essays on Richard Murphy testifies to the fact that, even if Murphy has not always been able to preserve and secure the firmament of his personal life, he has certainly succeeded in leaving for posterity the well-made poetry he dreamt of writing in his youth. As part of his Acknowledgements in the opening pages of the volume Benjamin Keatinge expresses his regret that Richard Murphy has not lived to see the outcome of the project undertaken when he was still alive. Indeed, but Richard Murphy would approve of this tribute to his achievements - not only for the quality of the scholarship contained in its pages, but also for its making Murphy's voice better heard, indeed integral, in Irish letters, in other poetic traditions, and amongst those of other poets who served as inspiration or who helped to shape his writing, such as W.B. Yeats, Ted Hughes, Dennis O'Driscoll, Philip Larkin, Theodore Roethke, Ezra Pound, and Robert Lowell. 


\section{Note}

The publication history of The Kick is marked by different subtitles, varying from "a memoir" in the first version published in 2002 by Granta Books, to "a life among writers" in the 2003 and 2012 versions published by, respectively, Granta Books and The Lilliput Press, and "a memoir of the poet Richard Murphy" in the latest version published in 2017 by Cork University Press.

\section{Works Cited}

Murphy, Richard. The Kick. London: Granta, 2002.

—. The Pleasure Ground: Poems 1952-2012. Bloodaxe Books, 2013.

Elsa Meihuizen is a senior lecturer in the School of Languages at the Potchefstroom Campus of the North-West University in South Africa. She teaches Academic literacy through Afrikaans and English. Her research interests include Afrikaans literature, South African English literature, European literature, and the semiotic functioning of language within different social contexts and practices.

elsa.meihuizen@nwu.ac.za

The Collected Letters of W. B. Yeats, Volume V: 1908-10.

Edited by John Kelly and Ronald Schuchard

Oxford: Oxford University Press, 2018. cxi + 1179 pp.

ISBN 978 - 0-19812-688-1

\section{Reviewer: Nicholas Grene (Trinity College, Dublin)}

"It is very pleasant here", Yeats writes to Lady Gregory in March 1910 from Dunsany Castle, where he was staying with Lord Dunsany, then a recently produced Abbey playwright. "I am left alone for my working hours \& have written a poem 'The Fascination of What's Difficult". He did not get much such leisure time to write poems in the three years covered by this volume, largely because of the distractions he lists in this lyric: "Theatre business, management of men". There were specific reasons why so much of his energy had to be devoted to the Abbey in this period. The Fay brothers, who had largely created the acting company, were edged out in January 1908, and Yeats as Managing Director had to assume many of Willie Fay's day to day responsibilities of taking rehearsals and directing the performers. With Lady Gregory away in Coole much of the time, and Synge increasingly ill with the cancer which killed him in March 1909, Yeats was often left in sole charge. For a brief time the playwright Norreys Connell was installed as Director, and eventually in 1910 the twenty-three-old Lennox Robinson, with almost no theatrical experience, was given a managerial role. But Yeats remained in the thick of it throughout.

And it certainly was a thicket. There were legal wrangles with the Fays as to what rights they had to perform Abbey plays in the US, and under what title they might perform 
them. There were constant decisions to be made as to which plays to stage in which venues when they toured in Ireland and Britain, restricted as they were by a number of the part-time actors who could not travel because of their day jobs. Within the company itself, there was always friction and discontent, part professional, part personal. There were rivalries between Arthur Sinclair, leading man after the Fays left, and Fred O'Donovan, the personable young actor taken on in 1908, who was to go on to a career in film and television. There was bitter jockeying for position between Sara Allgood and her younger, more attractive, sister Molly (Maire O'Neill), as O'Neill began to move into some of Allgood's previous parts. And then there were the love affairs: Allgood feuding with Sinclair (who was in love with her and jealous of her relationship with another actor), O'Neill, courted simultaneously by the manager of the Manchester theatre where the company played and the theatre critic G.H. Mair, whom she subsequently married. It is no wonder that Yeats, in "The Fascination of What's Difficult" called down his curse "on plays / That have to be set up in fifty ways / On the day's war with every knave and dolt", though reading these letters there can be little doubt he had a real taste for those day's wars.

There is an interesting passage in a letter to Gregory about the possibility of hiring a "young Trinity College man" who had made his mark in student drama. Yeats is very reluctant to take him on, largely for reasons of class. "I have always considered that the class we draw our actors from is an essential part of our success. A young man from Trinity College would be very unlikely to join us, to continue with us. A living wage to Kerrigan would not be a living wage to him". Many of the company resented the Directors' speaking of having taken the actors from "workshops and desks", including J.M. Kerrrigan, a regular member of the ensemble, who had been a journalist before becoming an actor. But with average wages of $£ 1$ a week, the actors were earning at an artisan level very different from the income to be expected by Trinity graduates. Yeats distinguishes between the mainstream commercial theatre and the Abbey with its need for a commitment to the enterprise by all involved - actors, playwrights and directors: "There must be corporate fealing" - the spelling is as eccentric as ever. Yet it is evident throughout that the Directors belonged to a management class quite distinct from the performers they managed.

Whatever his class, in terms of actual earnings Yeats was by no means well off. There is a touching passage in a letter of July 1908 to Mabel Dickinson, the physiotherapist with whom he was having an affair: "I am poorer that I ever was in my life. I was plunged in misery the other night by dreaming I had spent $3 / 6$ on strawberry ices - only my collected edition can lift me into opulent air again. Till then I must sigh for that 3/6". His eight volume Collected Works published by A.S. Bullen's Shakespeare Head Press in 1908 necessarily features prominently in the letters, notably in the decisions about the portraits to be included and their location. (Besides making use of an existing drawing by his father, J.B. Yeats, and an etching by Augustus John, he was to sit to several artists at this time, including John Singer Sargent and the sculptor Kathleen Bruce). Though the Collected Works did not definitively lift him up into "opulent air", it was a marker of his literary status as the leading poet in English of the time, famously in his own words "King of the Cats" after the death of Swinburne in 1909. His social stock was rising also; he dined with H.H. Asquith, the Prime Minister in November 1909, as part of manoeuvring by Edmund Gosse to get him a Civil List Pension from the government. This was a sensitive issue for an Irish writer of Yeats's nationalist convictions, and the $£ 150$ a year he was awarded in 1910 was to earn him the contemptuous soubriquet of "Pensioner Yeats" in later hostile press. But it meant a great deal to him at the time, as he acknowledged in a grateful letter of thanks, setting "me free from anxiety and from the need of doing less than the best I can". 
"I long for a life without dates and without any settled abode", Yeats wrote in September 1910. "If I could find that I could write lyrics again". Given the degree of his practical commitment to the theatre in this period, and the paucity of poems he was able to write as a result, the feeling is understandable. But location in one settled abode was hardly a problem for him. Nominally, home was Woburn Buildings near Euston, the rooms he rented for many years, and he habitually spent the summer months with Gregory in Coole Park. Yet he was always on the move back and forth between Dublin and London, with side trips to Manchester, Oxford or Cambridge, when the Abbey was playing there, lectures in Liverpool or Harrogate. Public transport of the time made this relatively easy. A new day service introduced in April 1908 meant that Yeats could leave Euston at 1.20 in the afternoon and be in Dublin at 10.15 that night. (Many a contemporary passenger making their way out to wait for hours in Heathrow or caught in traffic coming in from Dublin Airport might wish for as speedy a trip). Communications were equally rapid, with several postal deliveries daily, and the immediacy of the telegram service - though in one notorious case the fate of the Abbey was affected by a telegram boy being delayed by stray cattle blocking the road to Coole Park. The the wire to Lady Gregory asking should the theatre close on the occasion of King Edward VII's death was thus delayed, the Abbey stayed open, and its English patron Annie Horniman resolved to discontinue her subsidy.

The waspish Horniman was Gregory's rival as Yeats's patron. Both were devoted to the poet and his work, supporting him with emotional encouragment and practical help. Horniman gave a subvention to the costs of producing the Collected Works as well as her capital investment in the Abbey and the ongoing subsidy which was to be stopped abruptly in 1910. But in the end, it was no contest. Gregory had so much more to offer: the shared involvement in the Abbey, in which she was not only co-Director but prolific playwright, the comfortable quarters at Coole Park where Yeats did his best work, and their longstanding personal friendship. All of Yeats's closest relationships were with women. Though he told Dickinson that "Synge's illness has for the first time in my life made death a reality to me", he went on to confess "not a little to my wonder (considering how intimate we have been) it was the death of his imagination that has set me sorrowing". In spite of the affair with Dickinson, it is the relationship with Maud Gonne that remained paramount. The editors of this volume cast doubt on what has been the recent scholarly consensus that Yeats and Gonne did briefly consummate their love in 1908, but there is certainly a new tenderness in her letters to the man she calls "Dearest" for the first time. And she did appreciate the poems he wrote for her in the Green Helmet collection, responding to an advance copy of the book: "There is a danger of my growing very vain when I read these beautiful things created for me - thank you". The years from 1908 to 1910 were not a happy time for Yeats - when much later he published extracts from a diary kept in 1909 he entitled it "Estrangement" - but it was a very active period and one of considerable achievement, not least in keeping the Abbey going against all the odds.

With this volume as with the four before it, one stands in awe at the sheer scale of the project and the enormous diligence of the editors. From the beginning, the principle was to publish not only all of Yeats's extant letters, but to record every act of written communication from him, reconstructing lost letters from other evidence. This includes letters written by those acting as his agents, as in the case of a long, densely reasoned argument by the American lawyer John Quinn on an issue of copyright. Simply assembling the material from libraries all over the world, from booksellers' catalogues, and from private collections, must have been a huge undertaking, and transcribing Yeats's all but illegible handwriting a nightmare. The editors' overview offered by the fifty page introduction to this volume is masterly, making deft use of the detailed knowledge Kelly and Schuchard have accumulated. 
The text itself, all 975 pages of it, can be quite hard hacking for the conscientious reviewer trying to read it straight through. Inevitably there is a good deal of repetition, as Yeats fills in several correspondents with the same news. The annotation is utterly comprehensive; every single individual mentioned by Yeats, however glancingly, is identified and a detailed bio supplied. This means that quite often the footnotes, in their minute font, occupy half or two thirds of the page and Yeats himself, with his poor eyesight, would never have been able to read it. Sometimes one feels that less might have been more. At this time, Yeats was making his way through the 40 volumes of his collected Balzac in translation; do we really need a detailed synopsis of the plot of Les Chouans, which the poet himself dismisses as bad early work? However, it is ungrateful to carp. Volume V of the Collected Letters, like its predecessors, is invaluable as a reference work to scholars interested in any aspect of the literary and theatrical life of Ireland and Britain of the time. The Collected Letters, the first volume of which was published in 1986, still has twenty-eight full years of Yeats's life to come; it must stand as one of the last great monuments of twentieth-century scholarship in a mode which will probably never be repeated.

Nicholas Grene is Emeritus Professor of English Literature at Trinity College Dublin and a Member of the Royal Irish Academy. His books include The Politics of Irish Drama (Cambridge University Press, 1999), Shakespeare's Serial History Plays (Cambridge University Press, 2002), Yeats's Poetic Codes (Oxford University Press, 2008), Home on the Stage (Cambridge University Press, 2014), Oxford Handbook of Modern Irish Theatre, (coedited with Chris Morash), (Oxford University Press, 2016), and The Theatre of Tom Murphy: Playwright Adventurer (Bloomsbury, 2017). He is currently working on a book about farming in modern Irish literature.

ngrene@tcd.ie

Over the Backyard Wall: A Memory Book.

Thomas Kilroy

Dublin: The Lilliput Press, 2018. 238 pp.

ISBN 978-1-84351-749-8

Reviewer: George O’Brien (Georgetown University, Washington)

Written in an affable tone and straightforward style, Over the Backyard Wall will perhaps strike many readers as a thoroughly agreeable account of the early life and times of arguably the least well-known of that generation of Irish playwrights - with Brian Friel, Thomas Murphy, Hugh Leonard in the forefront - whose works comprise what might be called 'the silver age' of Irish drama which had its heyday in the 1980s and '90s. The book covers his intellectual journey from boyhood in the small town (or, because these distinctions matter down the country, what Kilroy calls the "market town") of Callan, County Kilkenny, to his breakthrough as a playwright with the production of The Death and Resurrection of $\mathrm{Mr}$. Roche at the 1968 Dublin Theatre Festival. The result is an engaging, informative, 
unassuming, record of the making of an eminent career in a changing Ireland, illuminated by the attentive intelligence characteristic of all the author's work.

So far, so good. But the record is not quite the whole story. Discernible within it, or emerging from it, is an account of a culturally significant and historically suggestive moment in post-war Irish writing. Admittedly, the author's primary focus on names and places, on memories of family, community and friendship could indicate that this secondary narrative, so to speak, may not be just a by-blow. Still, though he modestly calls his book "a mixed bag", it's a more artful memoir than this description suggests. Its subtitle alerts us to that - rather than containing memories for their own sake, Over the Backyard Wall is a book in which the act of remembering is not one of recovery but of view-finding and reflection. Further, ensuring Over the Backyard Wall is no commonplace set of recollections, it is interrupted on two occasions by fictional material, the first dealing with the taking of Callan by Cromwell, the second with the impact on two local children of a family of Nazis who settled near the town in the aftermath of the Second World War. Both of these episodes ensure that the scales fall from the eyes of the two young boys through whose perspectives the events in question are rendered.

Such an interleaving of discourses is not as strange as may first appear, being a version of the familiar, essential and inevitable memoir mix of memory and imagination. As Kilroy notes in an opening chapter which serves as an effective preamble to, not only his material, but to his interest in setting it down: "Historical fiction is another avenue of retrieval and is intimately related to memory. It is, in fact, an imaginative imitation of the process of memory. It can also provide a corrective to memory when the two are laid alongside one another as they are here". The subject in history and the subject in memory both need each other so that a necessarily complex encounter with, and adequate acknowledgment of, the past may take place. The relevance of such an outlook to fitful Irish efforts to cleanse those doors of perception that lead to personal and national history hardly needs to be underlined. As a child, Kilroy suffered from "lazy eye" (amblyopia), a condition in which the sight of one eye develops at the cost of that in the other, is still all too telling a metaphor for how Irish history and culture are regarded (not that the weakness is confined to Ireland).

Rather than expatiating on such impossibly large categories as history and culture, however, Kilroy focuses on the very personal faculty of sight as the primary means of how one encounters the world. This focus may seem unexceptional, based as it is on a physiological fact. In this case, however, there is more than physiology at work. Sight initially makes it appearance on the memoir's opening page as the inadvertent prompt (in the form of a cataract operation) for what follows. Not only did the operation improve Kilroy's sight to an entirely unexpected degree, but he now "began to see memories as something directly in front of me". Arising unbidden, these sights of the past, for all that they were no more than "vivid shards, splinters", were something to grasp, in the same manner as the scenes of childhood were when first encountered - thus the "often highly tactile" quality attributed to memories.

Both the transient scenes of boyhood's physical reality and their return in memory as incomplete though pregnant vestiges were not just occurrences. Rather, in both forms they are pathways to knowledge, prompts to feeling, instigators of appetites for the world. The physical act of seeing is complemented by the affirmative intellectual rewards of doing so. Childhood's "spots of time" (to use the Wordsworth model of youthful apprehension) are here consolidated by the awareness, balance and ability to contextualise acquired in later years. The swimming holes in Callan's King's River known as "Little Paupers" and "Big Paupers" were places in which to have memorable summer fun. But they attain what might be termed the full measure of their reality when it is learned that they were so named on account of having been used as baths by the big and little inmates of the local workhouse. The beauty of 
nearby Slievenamon coexists with the horrific burning of Bridget Cleary that took place in that mountain's shadow. Play in the open spaces around Callan takes place on the same ground on which Cromwell's siege of the town happened.

And there are many other instances of this type of doubling, which is to be expected from a writer for whom "[a]lmost everything I have written in fiction and for theatre has had a basis in history". The addition of an historical lens to what is visible in the immediate sense points out one way in which seeing can be believing, or at least is affirming. The possibility of such affirmation may also suggest the appeal to Kilroy of the theatre, a medium which combines a physical, three-dimensional representation of a vivid present surrounded by darkness, one effect of which is to give an audience (the public) a unique opportunity to see, to apprehend and to focus, all of which are preconditions for comprehending, or for coming to terms with the world that is not theirs, the world on stage.

Of those many instances Callan provides of past and present being interwoven, one seems particularly notable. It concerns Kilroy's parents, his pious, steely Republican mother, and his police-sergeant father, who very nearly went once too often to the dogs (he gambled compulsively on greyhounds). Both came from the west of Ireland, and "a return to the tribe" was part of Kilroy's childhood summers. Some of the most eloquent and insightful writing in Across the Backyard Wall is about the "uncanny pull" of the west in Irish writing, and the ways the appeal was answered. But the west also came to Norman Callan, making Kilroy's parents "outsiders all their lives" and ensuring that he and his siblings "had one foot in another Ireland that was very different to that of Callan". The ghost of a Gaelic heritage coexists with the actuality of a Pale-inflected birthplace. As Kilroy says, "It is ... little wonder that I grew so preoccupied with the divided self", though rather than explore in much detail the challenge of engaging with such divisions, Kilroy instead turns to two culturally esteemed figures who have each represented one of the cultural landscapes in question.

On the one hand, there is the painter Tony O'Malley, himself of western stock and reared in Callan, whose output, in part, celebrates the town's Gaelic stonemasons, whose work resembles "ghosts from the West of Ireland" (see note below). On the other hand, from nearby Bennetsbridge, there is the intellectual, critic, secularist and dedicated European Hubert Butler, bearing the name of one of the most prominent of all Anglo-Irish families. It is tempting to regard Kilroy as, in effect, accommodating both these distinct sources of cultural and intellectual endowment: indeed his career is noteworthy for both its imaginative palette and its critical acuity. But any idea of equilibrium that such a confluence of cultural sources might suggest is facile. Besides, "[w]hile I came to love the older Ireland, I knew that I also had to face the life of a small Irish town with its alternative history of conquest and anglicization, its awkward collisions with the modern".

That facing into small town life constitutes the essential story of Over the Backyard Wall, although the process is disguised, to an extent, by the homely, disarming connotations of the title that signals the standard narrative of boyhood - Huck Finn lighting out for the new territory, and all that. Not that Kilroy crossed the wall to escape Aunt Sallies. He was running towards the basically conventional freedoms of open space and friends to play with, a swim in the river and a tour of inspection through the town, rather than away from discouragements, strictures and narrow minds. In his family experience there is no misery, no repression, no loss. The state of the family union remained strong, even when the man of the house continued to throw money at bookies. This basic stability enabled Kilroy to make a successful transition to boarding school at St. Kieran's College, where among his many accomplishments, he became something of a "hair-oil hurler", a phrase begrudgers applied to the polished Kilkenny style of hurling. More importantly, secondary school proved eyeopening, not only for giving hints of humanist learning but for its of codes, hierarchies, 
rituals, boundaries and related aspects of a deliberately coordinated structure. The theatrical, or at least performative, quality of these enacted ideas of order made an impression in their own right and also, perhaps, by being antithetical to the formative freedom found by the younger Kilroy beyond the backyard wall. He thrived at school, his career there culminating in winning what at the time was a much sought after county scholarship to go on to university.

The boarding-school years are also an important part of the story, however, because they tacitly point to the idea that Over the Backyard Wall, in addition to its autobiographical appeal, is also the story of a generation. This becomes clear in its account of student days (and nights) at University College, Dublin, during which Kilroy meets and mingles with many young people with the same background, and energies, and who shared his interest in pushing the envelope of what may be thought and said. This interest, predictably enough, did not find favour with the authorities, and the various clashes recorded here are snapshots from a prolonged kulturkampf, in which the immovable objects of seasoned reaction try to hold out against the irresistible youthful forces of enlightenment lurching towards modernity. Kilroy's literary interests landed him inevitably in the front lines. But these interests also led him over college walls, so to speak, and into literary Dublin, where he enjoyed the company and support of other writers. Most notably, Mary Lavin's generosity as a hostess was an important resource for many of the emerging generation of Irish writers in the early 1960s, more so, arguably, than her work in the short story. (Regarding the latter, Kilroy pauses just long enough to pay eloquent, if conventional, tribute to "The Becker Wives"). Encounters with other writers - Patrick Kavanagh, Flann O'Brien, Benedict Kiely - also illuminate the scene. And, with generations in mind, an afternoon with Seán O'Faoláin is recounted which features a bumptious young Kilroy taking the older writer to task for spending so much time outside the country, a performance which, among other things, mortified his partner in literary adventure, the rather unfairly unsung Tom MacIntyre, whose death occurred as this review was submitted.

All heady stuff. Yet, before long, "I became conscious of the need to get away from Ireland". There still were other walls to scale. Kilroy's various trips in that golden age of hitch-hiking brought him to Greece, via Yugoslavia (where one of the sights that disabused him of his positive view of Tito was that of women doing heavy manual), to Spain, France and elsewhere. Of these, the visits to Greece and Spain seem to be have been the most significant; the former illuminating and enlarging those humanist sympathies initially stimulated at St. Kieran's, and the latter confirming his liberal outlook as a result of a run-in with a right-winger. Yet here too, personal experience, its novelty, excitement, risk, wonder and sunshine, does not seem to be entirely the whole story. What is also being implicitly articulated is the emblematic character of those experiences, their sense of being unconstrained, the cultural and imaginative nourishment they provide, the connections they afford to histories and traditions which are valuable for other than narrowly national or sectarian reasons. Kilroy acknowledges the value of the first-hand touch of Europe's sheer diversity and plenitude, its manners, modes of representation, ways of playing and historical semiosis. To fund these summer getaways, Kilroy worked in England, a country which hardly registers on his ultra-receptive consciousness and which seems to have had nothing to offer him at the time other than, as with many another (here unmentioned) Irish person, a pragmatic means to an economic end.

The European dimension was important for the generation, including Seán O'Faoláin, that preceded Kilroy's, too, of course. For younger writers, however, there was a greater need to lessen the gap between what Europe stood for and what Ireland stood in need of. The choices were not a simple binary between staying put and exile (or in O'Faoláin's case, travel and travel-writing). Instead, a European awareness became an active resource for that younger 
generation, laying out a pathway which the generation following Kilroy's has helped to expand, even if the relationship between Irish and European writing (as distinct from writers) still seems more tenuous than exchanges between the two might lead one to believe. In looking towards Europe, as he points out, Kilroy identified with a more general Irish orientation in that direction: "In fact it was possible, in the Dublin of the 1950s to see more professional productions of European and American plays, than perhaps is true of today". A list of playwrights follows, thus underlining the point, and this state of theatrical affairs also caught Kilroy's imagination, leading to involvement with the notorious, censor-provoking production of Tennessee Williams's The Rose Tattoo at the Pike Theatre. Not that matters European were confined to aesthetic or dramatic considerations. In the early ' 60 s, Kilroy was appointed headmaster of Stratford College, a Jewish school in Dublin whose pupils included some whose parents were Holocaust survivors (the shock of having one of those parents pull up her sleeve to reveal her camp number is another formative European encounter and obviously has a bearing on the fictional "interlude", "The Coming of Hitler"). Such arresting experiences also contribute to a Kilroy's still evolving understanding of the kind of Ireland that would be worth living and working for.

The Stratford College period was not to last, however, as prior to taking the position Kilroy had arranged for a year teaching at the University of Notre Dame, which might be considered the Vatican City of Irish-America. But Irish-America did not appeal: "it took me some time to recover from ... close-up experience[s] of ethnic aggression". This was not a charge laid against his colleagues in the English Department, among whom there were some first-rate minds. The intellectual highlight of the year, however, was a lecture by Lionel Trilling, not exactly a Notre Dame type. The appointment at Notre Dame was followed by another post at Vanderbilt University, in Nashville, Tennessee a few years later. Here, a different set of influences and connections were available, presenting attractions and challenges of their own. Among the connections was one with Flannery O'Connor, who considered him to be, as a letter of hers recalls, "the real thing" - Irish, that is - and goes on to say that, "Thos. Kilroy said the South more than any other part of this country reminded him of Ireland". Whether there were intellectual and cultural similarities between the South and Ireland, however, remains moot.

During the 1920 and '30s, Vanderbilt was home to a group of poets and intellectuals called the Fugitives whose cultural thought tended towards anti-modernism and in some instances seemed a genteel, high-minded version of blood-and-soil cultural politics. Kilroy came to know some of the group's members, but their appeal to him doesn't come across. He mentions only their manifesto, I'll Take My Stand (1930), and his meeting with one of the most die-hard of the group, Donald Davidson, hardly amounts to more than a photo of a relic. An encounter with another, Robert Penn Warren (arguably not a true Fugitive), is enlivened by the American's enthusiastic desire to know all about the Anglo-Irish, not one of Kilroy's strong suits, as he concedes. The contrast between these encounters and the kind of modernist initiation prompted by his European experiences is never directly drawn. And though, needless to say, Kilroy did meet some wonderfully hospitable and cultured Southerners, one gets the impression that he would feel more at home with Lionel Trilling - or, indeed, William Faulkner, who rises with a certain grandeur out of the generally flat surrounding cultural landscape.

His appreciation of Faulkner, a writer who also saw what living in history could do to a place, a community, or a person, unfortunately does not lead to a consideration of the historical events that were beginning to change, not only the South, but the whole country during Kilroy's time there - the events of the Civil Rights Movement. It was "my own ignorance about race" which prevented experiencing what was going on "in any direct way". 
But the same seems broadly true of the entirety of his American experience. Both the country and its culture seem far from his work. And the parting gift of a peacock feather that Flannery O'Connor gave him? He lost it. Whatever his view of America might be, his name has not been associated with the blossoming of Irish-American literary relations in the 1960s. Further, any resemblance Kilroy may have perceived between the American Civil Rights Movement and the Northern Irish one is not mentioned. The story returns to Dublin, with the concluding chapter focusing on theatre there in the 1950s and ' $60 \mathrm{~s}$ and ending with the author's first dramatic production. (It was not his first play, which was The O'Neill, not produced in 1973).

The concluding note is one of triumph, which no one would begrudge, and of transformation, as that first night of The Death and Resurrection of Mr. Roche marked Kilroy's graduation to the role and status of author. This is an office to be taken seriously, a complicated mixture of personal integrity and public trust, and Kilroy is obviously not happy that "I have lived through a time of careerism and the spectacle of writers who became extremely skillful in the management of their careers in the marketplace. You wondered where the value system of the artist resided". Such a statement opens a whole other debate about the course of literature in an Ireland of boom and bust which is outside the scope of a mere review. More to the point, the statement is also a tribute to Kilroy's own generation, one, as his well-knit assemblage of "shards, splinters" makes plain, did take on a reactionary university clerisy and its sponsors; did take drama over a backyard wall which, hitherto, had merely propped up kitchen comedies; did seek out Europe's humanistic lineage and its literary exemplars; and did venture towards the modern (or at least towards the renovatory) in thought and, not infrequently, in technique. A thoroughgoing Irish intellectual history would provide a fuller appreciation - and critique - of these attainments, and would conceivably place Kilroy in the forefront of the artist-intellectuals of his time (with his range of reference from John Berger to Leszek Kolakowski). But perhaps it is a more characteristically Irish approach to history to eschew systems and ideas and to dwell instead on the intimacies and particularities of communal spheres of experience. That is work for another day. For now, it is good to have the types of testimony which Over the Backyard Wall contains, to appreciate the unified and composed presence of the author in his world, and to see a personal story heightened and broadened by acknowledging its existence within greater and more farreaching contexts of time and change.

\section{Note}

O’Malley's essay, "Inscape - Life and Landscape in Callan and Country Kilkenny”, in William Nolan and Kevin Whelan, eds., Kilkenny: History and Society (Dublin: Geography Publications, 1989), is well a noteworthy expression of the painter's vision of his subject matter.

George O'Brien is Emeritus Professor of English at Georgetown University, Washington, D.C. He is the author of the acclaimed autobiographical trilogy - The Village of Longing, Dancehall Days and Out of our Minds. His academic publications include a study of Brian Friel, The Irish Novel, 1960-2010, and, mostly recently, In a Harbour Green: Celebrating Benedict Kiely.

obrieng1@georgetown.edu 
A New History of the Irish in Australia.

Elizabeth Malcolm and Dianne Hall

Sydney: University of New South Wales; Cork: Cork University Press, 2018. 436 pp.

ISBN 978-1-7820-5305-7

Reviewer: Pauric Travers (DCU Institute of Education)

For more than thirty years Patrick O'Farrell's magisterial book, The Irish in Australia (1987), has held the position of standard work on the subject. While some of its claims and conclusions have been challenged, it has remained the yardstick by which other work on the subject have been measured. With the recent publication of A New History of the Irish in Australia by leading scholars Elizabeth Malcolm and Dianne Hall, this looks set to change. Malcolm and Hall's book is an outstanding contribution to the field of Irish and Irish Australian studies. It complements rather than supercedes O'Farrell's work while gently refining some of his conclusions. In addition, it throws considerable new light on areas ignored in the earlier work.

In the preface to his book, O'Farrell commented that the Irish in Australia was "an impossible subject, too vast, too various, too complex, and too elusive". In the meantime, thirty years of scholarship and the availability of new sources has reduced the level of challenge from impossible to merely difficult. Malcolm and Hall take these challenges in their stride by marshalling an admirable range of evidence, approaches and arguments with considerable skill and imagination. The book lacks a central narrative and eschews any aspiration to be comprehensive but the variety of topics covered is impressive and diverse.

Following an interesting introductory chapter on the historiography of the subject, this new look at the history of the Irish in Australia is organised in three thematic sections: race, stereotypes and politics. The section on race includes chapters on the relationship between the Irish and indigenous Australians, the Irish and the Chinese and the controversial question of race, politics and eugenics. The discussion on the Irish relationship with the aboriginal population is fair and even handed. Arguably the Irish were both colonised and colonisers. In some instances, Irish convicts and settlers established positive relationships with indigenous Australians - in others, the story is less edifying. To their credit, Malcolm and Hall do not shy away from the evidence that Irish emigrants and their offspring were involved on both sides in the frontier wars between white settlers and aboriginals.

A central question for historians of Irish emigration is the extent to which the Irish emigrant experience differed from other emigrant groups and the extent to which it was shared. This question is addressed and at least partially answered in this book. By setting their discussion of the Irish in Australia in the context of events in Ireland and the experience of the Irish diaspora elsewhere, the authors clarify issues and events previously imperfectly understood by earlier historians. By including other immigrant groups, they have extended our knowledge and provided fresh insights. The novel discussion of the Irish and Chinese is an excellent case in point. Drawing in part on the burgeoning research on Chinese Australian history, Malcolm and Hall throw new light on parallel experiences of Irish and Chinese immigrants and the shifting relationship between the two groups when the social and economic status of the Irish began to improve.

The Chinese and the Irish suffered from contrasting stereotypes. The stereotypes of Irish women and of Irish men are the subject of two excellent chapters. The discussion is enhanced, as is the book as a whole, by the inclusion of numerous contemporary cartoons which graphically illustrate the normalisation of demeaning racist caricatures which reinforced prejudice in politics and employment particularly in the nineteenth century. 
Malcolm and Hall document in more detail than before the extent of "no Irish need apply" advertisements and demonstrate the extent to which they were expressions of stereotyped and gendered anti-Irish attitudes. While the level of discriminatory practices in employment varied over time depending on the wider context, it remains the case throughout the nineteenth and early twentieth century, some employers preferred not to hire Irish Catholics, especially for work in the domestic sphere. It should be said that, as Malcolm and Hall show, the Catholic Irish were not immune from exercising such discrimination against Protestants albeit, because of their social position, they had much less opportunity for doing so.

D.H. Akenson has noted that crime is a theme which runs through the literature on Irish emigration. This reflects contemporary opinion in Australia and elsewhere that the Irish were particularly prone to crime and were disproportionately represented in crime statistics. Historians including Akenson and O'Farrell have accepted this particular stereotype. Drawing on recent research, Malcolm and Hall present a rather different picture - the Irish in Australia were over-represented in public order offences especially drunkenness but not in more serious offences including violent crime.

Similarly they demonstrate the need for scepticism in approaching the vexed question of the Irish and madness. There is no doubt that in Australia, as elsewhere, the Irish were committed to psychiatric institutions in substantial numbers. While they do not reach firm conclusions, Malcolm and Hall point to the complexity of the issues involved and the importance of cultural and contextual factors which demand further research on the Irish asylum experience. This research should include a closer examination of those doing the committals as well as those committed and those doing the diagnosis. It might also include a focus on the relatively large numbers of Irish female committals.

The final section of the book on politics is the most conventional in approach although the conclusions are notable. The Irish involvement in politics is approached mainly through the lens of Irish Australian premiers and prime ministers. While some historians have celebrated the achievements of prominent Irish Australian politicians, the authors present statistics showing that, in proportion to their numbers, there were fewer such people who reached the summit of politics than might have been expected. They also show the extent to which the careers of leading figures such as John O'Shanassy, Charles Gavan Duffy, Bryan O'Loghlen were blighted by anti Irish prejudice. Given their background and social class, the latter two were not easily caricatured as Irish peasant or tribal chieftains, but that did not spare them from being tarred with the same brush.

Some historians such as the late Eric Richards have questioned the usefulness of categories such as Irish, Scots and Welsh as analytical devices in studying migration and immigration and have argued for a broader taxonomy which transcends but does not deny national components. One taxonomy which Malcolm and Hall consider but reject decisively is the Irish as Anglo-Celtic, a superficially attractive hybrid which obscures key elements of identity and experience. A comparative focus on wider European and global diasporas might offer valuable insights but this New History of the Irish in Australia demonstrates the enduring value of a more specific lens.

Pauric Travers is President Emeritus of St Patrick's College Drumcondra. A graduate of the NUI and the Australian National University, his publications include The Irish Emigrant Experience in Australia (Dublin, 1991). He is currently President of the Irish Historical Society.

pauric.travers@dcu.ie 
Notes to Self.

Emilie Pine

Dublin: Tramp Press, 2018. 180 pp.

ISBN 978-1-9997-0084-3

\section{Reviewer: Éilís ní Dhuibhne (Irish Writer's Centre, Dublin)}

Emilie Pine's collection of essays was published in 2018 and warmly welcomed by the general reading public, the media, and the critics. It was in the best-seller lists in Ireland for months, has won more than one literary award and has been translated to several languages. Typical of the response of reviewers in Ireland was that of Martina Evans, in the Irish Times "I've never read anything quite like these essays... It's the kind of book you want to give to everyone, especially young women and men" (Irish Times, 21 July, 2018).

The essay which has received most attention, at least in the initial days and in the media, is the first, about her father's illness. The opening line is sensational and shocking, and it is a harbinger of what is to come, namely a collection of pieces about emotional and physical vulnerability. While the frailty of her father is the focus of the opening piece, it is the fragility of the writer's own body and life that forms the central theme of the bulk of the collection: the chance which governs the human condition, the vagaries of the body, and her inability to control it. And as she is brutally honest about her father, so is she about herself at least as honest as any writer, or human being, can be.

The feminism of the book received less attention in the popular media than its sometimes harrowing content. From start to finish the writer's feminist view of the world colours both her immediate responses to events, and her analysis of them. It even affects her selection of themes: the essay on "bleeding and other crimes" refers to the universal pressure on women to be beautiful, clean, and fragrant, at any cost. A recurring idea is that girls and women are conditioned to be eager to please, to be liked, which often means being accommodating to the demands of others, especially to men. Women are also disadvantaged by a society which is governed by mores, and sometimes by legislation, which serves patriarchy, rendering them silent or afraid to speak out, or put down when they do speak out. She provides more than one example of such "put downs".

The book contains six essays: "Notes on Intemperance", "From the Baby Years", "Speaking/Not Speaking", "Notes on Bleeding and Other Crimes", "Something About Me", and "This is Not the Exam". The opening essay is a raw account of the challenges of helping an ill older parent, exceptionally challenging in this instance because the parent suffers from alcoholism, and also happens to live abroad in a country where the public medical services are even worse than in Ireland. Public discussion of this piece has focused on the alcoholism aspect. This is undoubtedly significant, in that it gives rise to emotions - blame, guilt, anger which would not be an issue, or be less of an issue, if the parent were ill as a result of having been knocked down by a bus, say. "It's your own fault!" is an inevitable subtext in this essay. "If only. . ." But the problems - the unexpected phone call, the moral obligation to drop everything and rush to the ill parent, the struggle with the hospital staff - will resonate with any adult child who is the ICE of a parent. Actually, I would love to have Emilie on my side and at my side if I were ill in a terrible hospital anywhere! Although there is no selfaggrandizement in the essay, she comes across as an able defender of her father, very sick in a chronically short-staffed, underfunded, unhygienic hospital. She has the quick wit, initiative and courage to do exactly the right thing in this emergency. Although she is critical of the pressure on girls and women to be subservient and eager to please, in this account she herself comes across as someone who has overcome that condition: she is forceful, assertive, and not 
at all worried about telling people in authority what to do. For instance, she buys a box of plastic gloves as soon as she arrives in the hospital shop. Not only that, she forces the nurses to put them on when they are nursing her father. Indeed, one could surmise that it is thanks to her and her sister, V., who travelled with her to Corfu, that her father survived his illness.

"Speaking, Not Speaking" describes, with some humour, the bizarre but painful experience of being the child of a marriage which ended in a separation which was far from amicable. The break-up happened when Emilie was five, and her parents did not speak to one another for decades: she became a go-between. Starvation, denial, compulsive lying, were some of the strategies she used as a child to cope with this difficult life. "Something About Me", perhaps the most striking and powerful essay in the book, deals with her teenage years. She lived with her mother and sister in London, fell into very bad company and put herself in dangerous situations. This is a terrifying chapter, if you are a parent or grandparent, or aunt or uncle; Emilie engaged in seriously risky behaviour, involving drugs, sex, and what was more or less casual prostitution, and - extraordinarily - managed to hide it completely from her mother - at least for a time. She survived and overcame these obstacles and has been very successful in her chosen career. But it is a career not without its difficulties, as explored in the final essay. And although some aspects of her life have turned out well, as she acknowledges, she has experienced as an adult the grief of miscarriage, the pain of "trying for a baby", and the heart-breaking disappointment of childlessness. That is the subject of the searing chapter, "The Baby Years", which will resonate with anyone who has been through that dreadful experience.

The trauma and tragedy at the core of the book, are balanced by joys - Emilie's love of her little nephew, of her sister V., and of her partner, R., and her mother, who could, I think, enjoy greater prominence in the memoir given that one suspects she played the major role in enabling Emilie to be strong, independent, and well-educated. Perhaps there is a reason for the omission, but still, I can't help but recall that I had the same feeling, much magnified, on reading Barack Obama's memoir, all about his absent father, with hardly a mention of his present mother.

Notes to Self is a sort of "Min Kamp" to use Karl Ove Knausgård's title for his autobiographical writings. Knausgård, whose work owes a debt to Proust, is certainly one of the main inspirations for what is indisputably the current trend for memoir and autobiography, for what used to be called, dismissively, confessional writing. It is a trend which I welcome and which I believe denotes something very positive about our present literary scene, a trend which provides stands in stark and interesting contrast with the current negative forces regarding the abuse and degradation of language - especially the English language - in many spheres of public life. Knausgård writes his life in great detail and at great length in six volumes, 3600 pages of autobiographical works, published between 2009-2011 - an exploration of "self", of identity and self-realisation. Who am I? Emilie Pine is necessarily much more selective than Knausgård in her choice of themes for this single volume. Her selection is thematic, but nevertheless it has a chronological spine and it is all about struggle, about dealing with the obstacles to self-realisation and happiness that life throws at one, and about strategies for finding contentment and fulfilment in spite of these difficulties. "The Baby Years", for instance, ends with her realization that motherhood is not the only path to happiness. She adores her nephew, spends time with him regularly, but also understands (not as a result of babysitting!) that there are advantages to a child-free life with a loving partner. The closing scene in this essay is a hymn to joy: "I see a life ahead of us, a shared life. A great life". And the closing lines of the book are "I am afraid. But I am doing it anyway".

While the essays are an exploration of self, a questioning of self, and a search for self, the personal experience is brilliantly contextualized - thanks to her feminist perspective. 
Emilie Pine's experiences are also the experiences of many women in western society. Her book has innumerable great qualities which make it readable, engrossing, compelling. It feels like an essential book. And it is the clear message, that her personal "struggle" is a universal one that makes it most essential.

And the writing? It is perfect. The register is informal but not patronizing, the tone intimate: "Let me take another step sideways here and let me tell you something I learned about myself this past year or so. Are you ready? I don't care about your feelings. I don't even know you, but I don't care how you're feeling, what you're feeling, or even if you have any feelings at all. Because, apparently, I lack empathy" (188).

The style mirrors the frankness of the content. But there is nothing haphazard about the composition. These are shapely well-wrought essays. Emilie Pine's academic field is drama, so it is perhaps not surprising that she knows how to create a dramatic effect. Her every opening line is arresting -

"I pee on sticks and into sample cups"

"My parents separated when I was five and my sister was a baby".

"I'm not here. That is what I'm thinking as his hands are on me, his hands and mouth and the rest of him ..."

"Famously, the trick of good writing is bleeding onto the page".

These first lines all have an element of surprise, or shock, but also a concrete physical image, indeed a concrete anatomical image, appropriately for a book which is much concerned with the body - pee, baby, hands, blood. In the body of the essays narrative and description are balanced by commentary and analysis: the permission to reflect, at length, is an advantage the essay has by contrast with fiction. Emilie Pine has said in an interview that she never considered fictionalising her material - and it would be good raw material for novels or short stories - because its power resides in its factualness, its immediate connection to reality. This is true; memoir has a power different from that even of fiction with an autobiographical basis. And it is the power of powerlessness, ironically: the writer is unprotected - or hardly protected - by the veil or armour of fiction, and readers clearly appreciate this. Words like "honesty", "frankness", "openness" are frequently used terms of admiration, in discussions of this book.

But the great advantage of the essay is that, as well as facilitating the impression that the narrative is closely connected to the real, it invites the author to reflect and comment, to ask questions. This can be done in fiction, but fiction will not, in general, tolerate too much authorial thought or commentary, and drama even less so. The fiction writer, like the playwright, has to rely much more on implication, and leave most of the commentary and interpretation to the reader.

In Notes to Self, Emilie Pine has dived into deep waters, and bravely and selflessly shared her experiences and her thoughts on key aspects of her life with us. She has used her chosen literary form, the essay, cleverly. She writes with dramatic skill, and as vividly and entertainingly as a novelist or short story writer, while analysing her material with the scintillating intelligence of a critic of literature and society.

"Tell the truth, and tell it slant", Emily Dickinson advises. The art of telling the truth in code is not to be underestimated, because that is the art of the storyteller, the novelist, the poet and the dramatist. But perhaps, in this era of outrageous and bizarre mendaciousness, the time has come to tell the truth straight. That is what Emile Pine has done, insofar as it is humanly possible, in this intense, brilliant, and feminist book.

Notes to Self is an intense, brilliant, and feminist book. 
Éilís Ní Dhuibhne, from Dublin, has written almost thirty books, including six collections of short stories. Her most recent books are Selected Stories (Dalkey Archive, 2017) and Twelve Thousand Days. A Memoir (Blackstaff, 2018). Her work has won many awards and she is a member of Aosdana, an Ambassador for the Irish Writers' Centre and President of the Folklore of Ireland Society.

enidhuibhne@gmail.com

Oscar Wilde and Contemporary Irish Drama: Learning to be Oscar's Contemporary. Graham Price

London: Palgrave Macmillan, 2018. 249 pp.

ISBN 978-3-319-93345-0

\section{Reviewer: Pierpaolo Martino (Università degli Studi di Bari “Aldo Moro”, Italy)}

Wilde was "a man of theatre". His was a theatre that pointed to the centrality of the dramatic aspects of everyday life. As American poet G. C. Waldrep has noted, Wilde's own performance was part of his "self-promotion, which fed his professionalism". Wilde, had a theatrical sense of life, his was a Bakhtinian dialogical interiority in which, as in a play, different personae spoke to each other without ever reaching a fixed, immutable truth (or identity). Although the relevance of plays such as Lady Windermere's Fan and An Ideal Husband, is unquestionable, Wilde's most successful play of the 1890s remains The Importance of Being Earnest (1895) which, in a sense, mirrors Oscar Wilde as a living play with its focus on masks, double identities, inversion of gender roles and verbal complexities. The very title of the play refers to the idea of performance, to the importance of being, playing, performing someone else in particular contexts. Yet this is also a permanent condition: we are the differences, the different roles which we enact every day. The play reflects Wilde's interest in gender issues, questioning, within a consumerist context, the normative and rational aspects of Victorian masculinity. It focuses not so much on women's "irrationality" (as was the case with An Ideal Husband) as on men's queerness, elaborating upon the work he had done months earlier on the character of the dandy, namely, Lord Goring. All of his plays show his fascination with the very idea of liminality. Wilde's most interesting feature is indeed his ability never to take sides, his refusal of a fixed, predictable, frame of mind, in short, his resistance to the irreconcilability of contradictory realities. One should never forget that while performing the role of the perfect "Oxonian" he remained an Irish man at heart.

In this sense, Graham Price's Oscar Wilde and Contemporary Irish Drama: Learning to be Oscar's Contemporary locates Oscar Wilde alongside J.M. Synge, W.B. Yeats and Samuel Beckett as a central influence on contemporary Irish theatre. Price examines Tom Murphy, Brian Friel, Thomas Kilroy, Marina Carr, and Frank McGuinness as embodiments of a specific Wildean strand in recent Irish drama. These Irish dramatists are, as the author explains, not by any means the only ones to owe a debt to Wilde, but they are the playwrights for whom the Wildean aesthetic is most tangibly present in their work

Price shows how what is particularly relevant is the subtle and implicit moments of Wildean intertextuality that occur in plays such as Faith Healer and The Gigli Concert where 
the ghost of Wilde's work is implicitly present on the level of theme and/or style. In a sense, as the author points out, Wilde has become such an influential figure in the development of the cultural ethos that surrounds Irish drama that his presence can, at times, manifest itself in plays without the author's explicit knowledge or intention. In this sense Julia Kristeva in Desire in Language: A Semiotic Approach to Literature and Art, defines inter-texuality as the passing of meaning from a writer to a reader through the mediation of "codes" that are derived from other texts. The use of the word "code" by Kristeva implies a much more subtle form of influence than the simple, direct quotation of another author's oeuvre. It points towards one writer borrowing from and alluding to another in an implicit rather than explicit manner that can at times be hard to detect. How the chosen dramatists depart from, and in some cases sub-vert, Wilde's work at certain critical moments in their texts is in this sense particularly relevant. This seems particularly relevant to the analysis of The Gigli Concert which is a play that uses many of Wilde's aesthetic theories only to rewrite and depart from them in key scenes.

Contemporary Irish drama's engagement with Wildean aestheticism is clearly investigated during the book's analyses of Brian Friel's Faith Healer and Tom Murphy's Gigli Concert. These two plays use Wilde's theories concerning the relationship between art and life in a manner that signals, not only their endorsement of Wilde's critical positions, but also an unease concerning the potential effect on an individual's ethical life if they renounce the physical world which they share with others for one of ego-centricity facilitated via the medium of art and aestheticism. In the above-mentioned plays by Friel and Murphy, a productive union between the real and the artistic, the natural and the aesthetic, is staged in potential opposition to what could be regarded as Wilde's more unproblematic privileging of art over life.

Mary Butler's conception of gender construction and how the norms of gender and sexuality are produced and maintained within certain societies is extremely important in the chapter dedicated to Marina Carr's relation to Wilde because her plays are very often concerned with so-called bad and good women and the threat that rebelliously non-normative females pose to the body-politic. In this sense Wilde's Salome is an important precursor to the domineering, powerful and frightening women that dominate Carr's dramas.

In this important book Price analyses, in addition to Wilde's plays, a vast range of his non-dramatic works, and their relevance to contemporary Irish dramatists. Because of Wilde's proficiency in many different genres, including literary and theoretical essays and dialogues, Price stresses that he, no less than Yeats, played a vital role in the shaping of a cultural and artistic zeitgeist in Ireland that continues to inspire writers.

We could add that Wilde played a central role in the very shaping of the idea of postmodernity as a whole. In this sense we can think of his last and most famous play - The Importance of Being Earnest - as exceeding its power on the page and the stage: the importance of being Earnest turns, in this way, into the importance of being Oscar, who in turn becomes the symbol of life as theatre and of a postmodern, ironic approach to identity.

Thanks Oscar.

Pierpaolo Martino is Senior Lecturer of English Literature at the University of Bari, Italy. He is the author of Virginia Woolf: la musica del faro (2003); Down in Albion: studi sulla cultura pop inglese (2007); Mark the Music: The Language of Music in English Literature from Shakespeare to Salman Rushdie (2012); La Filosofia di David Bowie, Wilde, Kemp e la musica come teatro (2016); and editor of Exodus: studi sulla letteratura anglo-caraibica 
(2009) and Words and Music: Studi sui rapporti tra letteratura e musica in ambito anglofono (2015).

pierpaolo.martino@uniba.it

Emergency Writing: Irish Literature, Neutrality, and the Second World War. Anna Teekell

Evanston, Illinois: Northwestern University Press, 2018. 261 pp.

ISBN 978-0-8101-3726-4

Reviewer: Christina Hunt Mahony (Trinity College, Dublin)

"The Emergency", an exclusively Irish sobriquet for the Second World War, and was a word used for the euphemistic method of isolating the new Republic from the threat of having its autonomy cut short by international conflict. Language became and remained the chief means of enforcing that neutrality both from within and outside the 26 counties.

Anna Teekell's book is about that language - about the rhetoric of the Irish government in the first instance, but also about the literary responses to that rhetoric and to Ireland's position during the war years. In five extremely readable chapters she studies both the language of the poetry and the prose of the period, pairing Patrick Kavanagh and Denis Devlin's work in one chapter, Samuel Beckett's and Flann O'Brien's in another, and devoting a chapter each to Louis MacNeice and Elizabeth Bowen. Other writers, including Sean O'Faolain, Kate O'Brien and Máirtín Ó Cadhain are discussed along the way.

Much of the analysis is conducted through the lens of Ireland's contested and belated Modernism and its response to governmental manipulation of language and censorship during the war. Teekell asserts that - "Much of the literature of the Emergency is a response to the government's attempt to legislate aesthetic autonomy, as well as an acknowledgment that if modernist forms are no longer capable of making things new, they are still capable of disrupting dominant cultural narratives". Another of the book's strengths is the linking of concepts and material not previously examined in the same contexts. For instance, Chapter I "The Rhetoric of Irish Neutrality" - begins by examining a 1937 article written by Michael Tierney, a Mayo TD who would become president of University College, Dublin. Tierney argues that the Irish course during the war should be guided by "sacred egoism", thus linking the concept of neutrality then to a much earlier Sinn Fein anti-conscription stance taken during the Great War. Sacred egoism was in turn linked to both self-sufficiency and the moral high ground. Positioning neutrality thus diminished the chance of the policy being seen as self-serving. Furthermore the use of censorship during wartime could be extended from protecting Ireland from an outside threat, but also threats to its moral fabric, the rubric under which the infamous banning of The Tailor and Ansty was enabled.

The in betweenness (italics mine) which was the condition of Ireland and its writers, and indeed all its inhabitants during the period, found expression in likening the state of affairs to the purgatorial, thus in the following chapter - "Pilgrimage as Poetic Form" - the author centres her discussion on the wartime poetry of Patrick Kavanagh and Denis Devlin, but most specifically on their respective poems on Lough Derg, aka Saint Patrick's Purgatory, 
both published in 1942. The pilgrimage, perhaps better known to today's readers from Seamus Heaney's well-known serial poem "Station Island", has been the subject of literary works in Ireland and elsewhere in Catholic Europe for centuries. Twentieth century pilgrimpoets often undertook the rigours of the Lough Derg pilgrimage with an attitude that can be defined as agnostic, or at the very least, "at a tangent" (as the figure of Joyce in Heaney's poem advises), or by preferring to "tell it slant" as Emily Dickenson famously suggested.

The unease that comes with being in between, neither/nor, or from some of the more negative connotations of neutrality continue to feature in Teekell's next chapter entitled "The Enemy Within". This section of the book covers Louis MacNeice's war poetry and in doing so presents the author with a greater challenge in that this body of work has been examined in the same context time and again in the ensuing decades. Teekell is familiar with, and makes use of, earlier scholarship on the subject from that of Edna Longley to Tom Walker, while also illuminating MacNeice's relation to the work of Yeats in his critical book The Poetry of W. B Yeats. In what was the first critical book written about Yeats' work, MacNeice takes particular interest in Yeats' uneasy, fluctuating but ultimately resolved, intellectual position in relation to both the Great War and the Easter Rising and the Irish Civil war - particularly in his volume The Tower.

Teekell takes issue with Heather Clarke's contention that MacNeice's 1938-45 poetry was his most English period, siding instead with Tom Walker's view that the 40s was perhaps MacNeice's most Irish decade. More importantly the author argues that MacNeice had a view of neutrality that eschewed any trappings of nationalism. This is territory covered, of course, by Edna Longley who questioned whether the betweenness of MacNeice, and his use of the word "between" in verse of the period indicated separation or being conjoined.

This chapter focuses on Springboard, the volume published in 1944. In the title poem, as in others in the collection, there is awareness of suicide, despair, images of crucifixion. "Conversation" carries with it, at least from the vantage point of the post-war reader, that hint of secrecy or spying. Teekell rightly posits the notion that the whole collection emits a nervousness or tension emblematic of the wartime experience on the home front - the permutation of personality affected by outside events that ordinary people were powerless to control. And, of course, the volume also addresses, if obliquely, the concept of survivor guilt. Its destructive and purgative fire imagery is pervasive, depicting the inferno of London during aerial bombing. By contrast "Neutrality" and the other Irish poems seem nearly bucolic, but they are never easy in themselves, instead asking questions to which there are no easy answers for the poet.

I would have liked Teekell to include an examination of the next volume in MacNeice's corpus, Holes in the Sky, in which unvarnished and rather despairing references to looting, food queues, distrust and war fatigue in poems written between ' 44 and ' 47 paint the home front in unflattering terms which would garner negative reviews in Britain calling called attention to MacNeice's dubious position as an Irishman to render such judgments. One such poem, "Corner Seat", might have segued into the discussion of Elizabeth Bowen's wartime novel of espionage and treason, The Heat of the Day, discussed in the ensuing chapter. In the novel the central character, Stella, travels by underground grimly imagining the carriages on the return trip being lighter minus the weight of the bodies of people who would be killed in that day's bombings.

Teekell's main contribution in the section on Bowen is to link the language of Bowen's Court (the author's autobiographical history of her ancestral home in County Cork) and two of her most well known short stories, "Mysterious Kôr" and "The Happy Autumn Fields", all written in much the same time frame. Here Bowen's grappling with neutrality takes shape in the form of syntactical inversion and complexity in her adamantly opaque 
prose. This is writing that does not easily yield its secrets, as Bowen, who managed to travel back and forth to Ireland (and to Bowen's Court) when such travel was very limited, hid her undertaking to supply the British MOI (Ministry of Information) with reports of attitudes and activities in Ireland. Many in Britain viewed Ireland's neutrality as being treasonous; and in The Heat of the Day, which takes place in both countries, Bowen is at pains to deconstruct the tension of complex loyalties.

While MacNeice and Bowen spent much of the war in London and many shared experiences, Samuel Beckett and Brian O’Nolan had very different wars - Beckett becoming a member of the French Resistance, and O'Nolan bitterly watching his masterpiece, At SwimTwo-Birds, published in 1939, fade from critical sight. Teekell's final chapter links the unresolved purgatorial conditions of Beckett's Watt and O'Nolan/O'Brien's The Third Policeman, written at the same time, and also contemporary with the Irish language entry, Cré na Cille, by Máirtín Ó Cadhain, written while the author was interned. In the latter the speakers are all dead (interred, not interned) and buried in a Connemara graveyard. Their condition renders them in between the life they have left on earth, but not yet accepting of the afterlife. Thus their torment. Similarly Beckett's Watt dwells on the title character's experience of death, and The Third Policeman is set in a similarly nightmarish world from which there is no escape. The purgatorial in most of these examples of wartime writing suggests expiation, but that is in the context of having to endure a long wait for same. In this sense, perhaps, allusions to the readily available and equally liturgical limbo would have been apt.

The Epilogue to Emergency Writing indicates just how far Ireland has come in its view of the country's wartime neutral stance. Teekell presents a short analysis of Arthur Riordan's riotous musical in verse, Improbable Frequency, produced by Rough Magic Theatre Company in 2004. Featuring as characters Myles na gCopaleen, John Betjeman and Erwin Schrödinger (an Austrian physicist recently arrived in Ireland who headed De Valera's Institute for Advanced Studies during the war) interacting in highly unlikely ways in Emergency Dublin, the play includes production numbers which rivalled those in "Springtime for Hitler", Mel Brooks' play-within-a-play in The Producers. A play about the use and misuse of language - one of its central characters is a crossword puzzle expert trying to decode Irish weather forecasts on the radio and their potential for transmitting classified information to Nazi Germany - its final duet between the lovers, English Tristan and Irish Philomena, ends, significantly, on an "unresolved" chord, signalling once more the complexity of writing about neutrality.

Christina Hunt Mahony is the former director of graduate Irish Studies at The Catholic University of America in Washington, DC. She is the author of Contemporary Irish Literature: Transforming Tradition and Out of History: Essays on the Writings of Sebastian Barry. She is a recent contributor to The Oxford Handbook of Modern Irish Theatre, ed. Nicholas Grene and Chris Morash, and to A History of Irish Autobiography, ed. Liam Harte.

cmahony@tcd.ie 
James Joyce's Silences.

Edited by Jolanta Wawrzycka and Serenella Zanotti

London: Bloomsbury, 2018. 272 pp.

ISBN 978-1-3500-3671-0

Reviewer: Teresa Prudente (University of Turin)

As suggested by the plural in the title, silence in Joyce takes the form in this volume of a web of different interweaving directions, both in terms of content and methodologies, as the entire range of the Joycean corpus is here explored, and silence is interpreted and analysed from different perspectives. This is evident from the opening essay by Fritz Senn, where silence in Joyce is deconstructed via the analytical disentangling of instances that point to many interlacing directions and functions, including the rhetorical, epiphanic, and evasive. Senn offers a poignant conceptual catalogue which provides a solid scaffolding for the inquiries developed in the following essays. His essay also sets the textual ground for considering the tension of opposite forces animating Joyce's rhetoric of silence, especially those between emptiness/presence and activity/passivity.

The dynamics between staging and stating silence are explored by Rosa Maria Bollettieri-Bosinelli and Ira Torresi, who reflect on how Joyce exploits theatrical forms in his writing in order to fully deploy the epiphanic effects of silence. Quoting instances from Dubliners, Epiphanies, Stephen Hero and Ulysses, the authors point out how silence claims the scene and becomes visible and audible with implications that relate it to the taboo discourse of death. The idea of silencing the unspeakable as a way of making it more present and effective is explored in further essays in the volume. Forms and implications of the unsaid are explored in relation to the many semantic areas as well as narrative and linguistic forms they acquire in Joyce. Morris Beja provides a set of instances from the Joycean corpus relating silence to scorn and "separation, distance, aloneness, indifference, desperation, exile" (115). In Laura Pelaschiar's essay, instead, the unsaid is explored in its political implications with reference to the silencing of the female voice: the author's point is in line with the previously mentioned idea that Joyce's focus on silence is able to make the unsaid/untellable even more present and audible than what is told. This is argued by Pelaschiar via the textual genetic analysis of Joyce's revision of his first short story, "The Sisters", where the writer "discovers and expands the potential of the rhetoric of silence" (35) in relation to the female subject. A complementary perspective on Joyce's politics of silence is proposed by Teresa Caneda Cabrera, who interprets silence in "The Dead" as a technique calling attention to the unsayable, read this time in relation to the Irish historical and political context and, especially, to the Joycean focus on the feeling of foreignness. Silence, that operates in the short story by "evading complete articulation and withholding voice" (95), becomes thus an aesthetic and narrative instrument pointing at the unsayable aspects of Irish culture, history and society, but also, more broadly, at the potentiality of literature to give voice to estrangement, isolation and displacement. The focus on aesthetics, exploring the nexus between content and form, is at the centre also of John McCourt's analysis, which traces the development of Joyce's style from Giacomo Joyce to Ulysses by following the multiform role played by silence in the process, especially in relation to its opposite, noise, and to alternative forms of expression such as gesture.

Joyce's language of silence is the object of Sam Slote's analysis of the "Penelope" chapter in Ulysses in relation to Beckett's dynamics of affirmation and negation in The Unnamable and How It Is. Slote's internal deconstruction of Molly's yeses shows how in the chapter they perform a range of functions, from semantic to syntactic, that "indicate the 
copula of continuing discourse" (109) in a writing process where "every step taken is also a step retracted: the path forward is aporetic" (110). Forms of affirmation in Joyce and Beckett can thus be read as affirmations of inability, "a great Yes to death" (112) that simultaneously encapsulates negation. The implications of Joyce's focus on the dynamics of language and silence is at the centre also of Laurent Milesi's dense essay, that links the discourse of silence to that on the origin of language, seeing silence as return: the silence "from which language arose and to which is condemned to revert" (63). By dwelling deep under the surface of Finnegans Wake's Babelic form, Milesi argues for silence as an essential constituent of language - and the language of Joyce. This is proved by how some of the Wake's main topoi point at the close connection between silence and origin, in the form of a lost and legendary source (the quest over the origin of Nile, the possible reference to the mythological river Alpheus) which, in a Blanchotian reading, brings language back to confrontation with its most essential aporia: the perpetual challenge against ineffability.

While some essays in the volume approach silence in a more indirect way - William Brockman's analysis of Joyce's dictated letters, where the writer's voice, mixed with those of the amanuenses, is allowed silence and thus less responsibility, and Sara Sullam's analysis of how the history of the Italian publication of Joyce's critical writings, retraced in the publishers' archives, shows that Joyce was "silenced" by censorship - Tim Conley's essay brings the discourse back to the nexus between language and silence, while also serving as a bridge to the section devoted to translation. Conley starts from the polysemy of translation with reference to the different translations provided, in English and further languages, to periphron, the Greek adjective qualifying Penelope in the Odyssey, to argue for the various forms in which Molly Bloom's language is "translated" in Ulysses. Within the context of Conley's point - that Ulysses works as a translation of the Odyssey - the multiform textual construction of the feminine voice in the novel shows Joyce's attempt of "translating" silence via a set of strategies, such as onomatopoeia and idiosyncratic punctuation, that deconstruct stereotyped assumption on women's language to show "the eternal feminine as an everimminent moment of communication, a way of speaking without spoken words, a way of speaking beyond death, in a silence of one's own" (164). The relationship between silence and translation is then approached in three essays that show different takes on the subject. Serenella Zanotti focuses on silent translations: the Italian versions provided by Joyce in his early critical writings when quoting from the English of other authors and critics. Arguing for transformations that make the translations more than instrumental, Zanotti shows how silent translation works in Ulysses, especially in relation to references to Dante, and sets itself as one of the most pervasive features of Joyce's building of complex intertextual webs. Jolanta Wawrzycka's essay provides a foundation and examples for her translation into Polish of the poems of Chambers Music, explaining how her work was guided by the "translational philosophy of literary relanguaging that proposes, after Ingarden, to preserve all layers of a work of art" (196). Focussing on the poems' phonemic structures, and the ways they point to silence, the author offers an analysis of her translation choices in the context also of a previous Polish translation as well as two Italian translations. A similar attention to the soundsense element characterises Erika Mihálycsa's analysis of music and silence in Ulysses via the examination of two Italian and one Hungarian translations of the novel. Focussing especially on how translation confronts the aural quality of the Sirens episode, Mihálycsa argues for silence as an essential constituent of translation, in light of the fact that "a deliberate stopping short of mediation, of the transfer of meaning, is a gesture that provokes translation and faces it with its limit" (225). The coda of the volume is an essay by Franca Ruggieri which sets Joyce's poetics of silence in the context of the Modernist experimentation and cultural revolution, seeing the work of Joyce, as well as that of Conrad, Eliot and Kafka, as examples 
of how Modernism approached silence as a "multifarious associations of ideas, metaphors, and oxymora" (233).

As it is evident from this overview, richness of stimuli and suggestions, as well as textual cues and evidences, characterise this volume, which proves a fascinating and useful reading for Joycean scholars, although the same richness may also prove a limitation, as one might wish, in some cases, that some of the contributors had more space in which to fully develop their arguments. Nonetheless, the wealth of approaches and textual interpretations offered by the volume provide a platform in the field of Joycean studies that may give rise to further investigations.

Teresa Prudente is Associate Professor of English Literature at the University of Turin, Italy. She has authored a monograph on Woolf's temporalities (A Specially Tender Piece of Eternity: Virginia Woolf and the Experience of Time, 2009) and a book on Woolf, Joyce and science (To Saturate Every Atom: Letteratura e Scienza in Woolf e Joyce, 2012), as well as edited and translated into Italian Shakespeare's The Two Noble Kinsmen (2015).

teresa.prudente@unito.it 